\title{
IMPROVING STUDENTS' READING COMPREHENSION THROUGH COOPERATIVE INTEGRATED AND READING COMPOSITION ON NARRATIVE TEXT
}

\author{
Matheus Ferry Renaldo ${ }^{1}$, Lia Nurani ${ }^{2}$ \\ ${ }^{1}$ IKIP Siliwangi \\ ${ }^{2}$ IKIP Siliwangi \\ ${ }^{1}$ matheus.ferry@gmail.com, ${ }^{2}$ liaanurani@gmail.com
}

\begin{abstract}
This study is revealed based on the observation on the tenth grade of SMKN 3 Cimahi. The subjects of this study consisted of 34 students. The purpose of this study was to improve the students' reading comprehension using Cooperative Integrated and Reading Composition Method. The research design was Classroom Action Research (CAR) which following Arikunto model. It is used to obtain the results of qualitative data using two cycles described through planning, implementing, observation, and reflection on each cycle. The result of the study showed that there was a development on the students' reading comprehension. It could be seen from the result of the test. The Minimum Mastery Criterion (KKM) of English lesson was 70 (seventy). The students mean score in the first test was 50, in the first post test the mean score was 65 , and in the second post test the mean score was 85 . In addition there were 3 students $(8.8 \%)$ who passed KKM on pre test. In the first pretest there were 9 students $(29.41 \%)$ who passed KKM. In the second pretest there were 31 students $(91.18 \%)$ who passed KKM. Then, from the result of observation and interview it showed the positive responses from the students. The students can be more active and improve their ideas. The researchers conclude that Cooperative Integrated and Reading Composition method could improve students' reading comprehension.
\end{abstract}

Keywords: Cooperative Integrated, Narrative Text, CAR

\section{INTRODUCTION}

English is a foreign language and the second language in Indonesia which requires several skills such as speaking, listening, reading and writing. As one of the lessons in school and faculty, reading also plays an important role because reading has a part of our daily lives. In addition, there is also a collection of research findings that support reading comprehension about learning experiences that are understood and systematic (Friska, 2018). According to Zwiers (2004: 3) as cited in Parmawati (2018) reading habits more clearly describes the automatic and unconcious process that are involved in constructing meaning from text. To discuss how to read, the teacher must help students to read the text by understanding and modeling how to read for them, which means the teacher must discuss strategies that are appropriate for learning to read to make the learning process effective. Because each class has a different ability in reading skills, especially in understanding a text, it will also determine the right strategy in each class. A suitable strategy will have a positive impact on the teaching and learning process.

English in Indonesia is a foreign language, most students at any level of education get difficulty in reading English text. (Apsari \& Yana, 2015). In SMKN 3 CIMAHI many students rate English texts very difficult to understand. Based on researchers 'observations, students' problems in reading comprehension arise due to several factors. First English text is not easy for them; they often invite complaints when facing them. Second reading is considered 
something boring by students. This condition supports teachers to make appropriate learning materials and good techniques to improve their reading comprehension.

Based on the description above, this study attempts to increase the use of strategies to improve students' reading comprehension. This method can accommodate different ability level of student (Choiri, 2017). Integrated cooperative method and reading composition consist of various elements that can support the improvement of students' speaking skills. One of them is the meaning of words, words that are difficult to read and understand in groups. This element can overcome the problem of children who are late in understanding the concept of a story. Besides that the cooperative model is also very helpful for students. According to Fitria (2015), CIRC technique is one of the learning techniques based on cooperation, is designed to develop reading, writing and other language skills. CIRC technique presents a structure that increases not only opportunities for direct teaching in reading and writing but also applicability of composition writing techniques. She adds that skill-based reading groups approach encourages development of this technique.

Here the researchers conducted a study based on "Increasing the Understanding of Cooperative Students Integrated Reading and Composition of Reading in the Narrative Text"

\section{METHOD}

The setting of this reasearch is SMKN 3 CIMAHI. The researchers focus to the tenth grade X PH 2 which consists of 34 students. The design of this research was Classroom Action Research (CAR). According to Mubarok \& Sofiana (2017), "the aim of action research is to solve the problem and make improvement of the teacher learning process in the classroom, beside that action also used to investigate the major problem and how to solve the problem"'. The researchers use Classroom Action Research by Arikunto model which consists of four steps, there are : planning, implementing, observing, and reflecting.

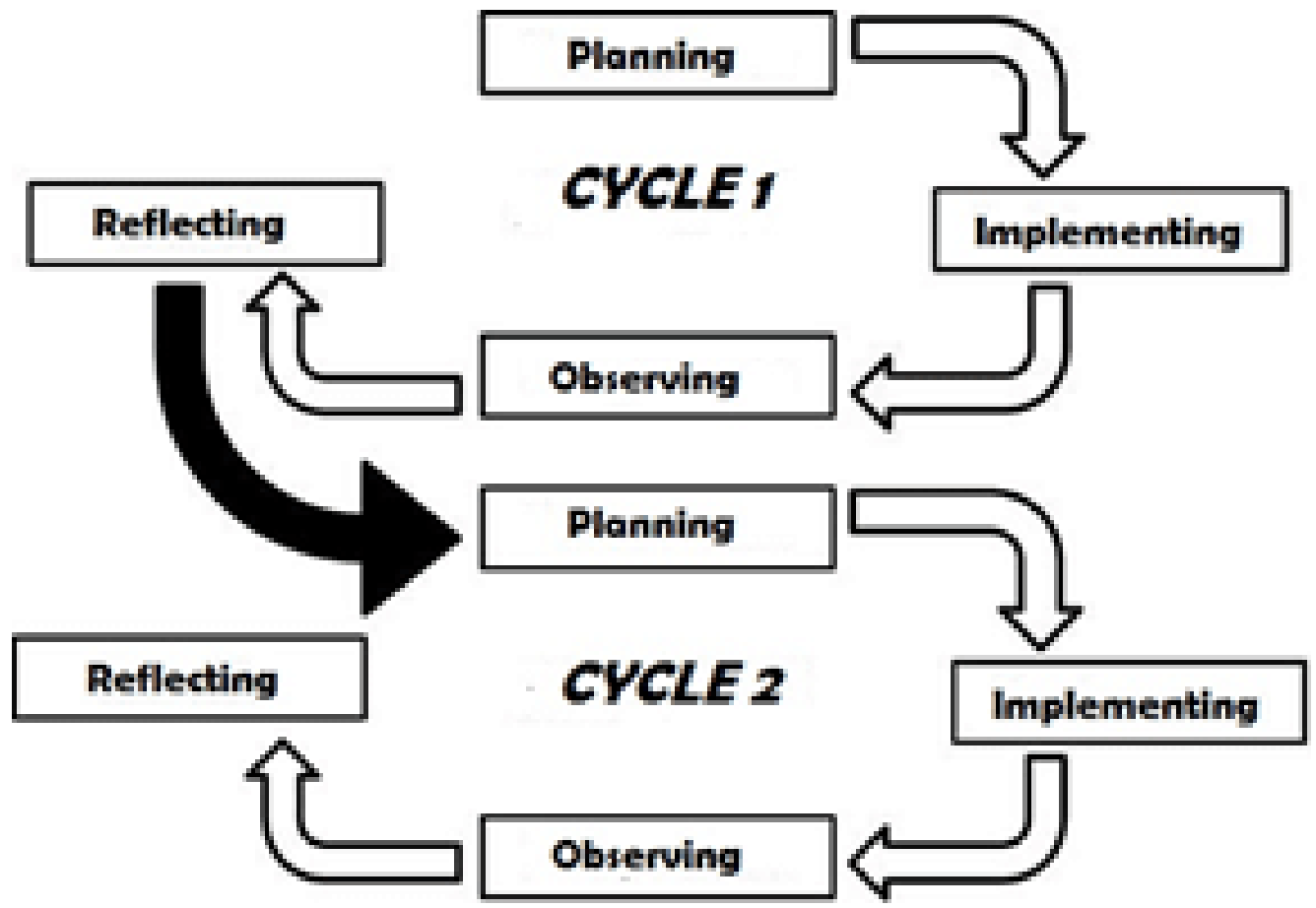

Figure 1. Diagram of Classroom Action Research adopted from (Indriyanti \& Prasetyo, 2018) 
The researchers use two cycles that consist of seven meetings. The first cycle consisted of four meetings, those were : Pre Test, Treatment 1, Treatment 2, and Post Test. The second cycle consists of three meetings, that is : Treatment 3 , Treatment 4 and Post Test.

The researchers uses qualitative data consists of observing. Observing was to record activities during teaching learning of reading comprehension on narrative text through Cooperative Integrated and Reading Composition in the classroom, including description of students' attitude, the teacher's creativity in presenting the material and the classroom's atmosphere. While the, quantitative data consist of a test, that is : Pre Test and Post Test. Pre Test before implementing the Cooperative Integrated and Reading Composition method and Post Test after implementing Cooperative Integrated and Reading Composition method. The test was to measure the ability of students' in reading comprehension on narrative text.

\section{RESULTS AND DISCUSSION}

\section{Results}

\section{Test}

Test in cycle 1, researchers found that $26.47 \%$ or 9 of 34 students received grades that passed the KKM. It does not give good results in increasing student mastery. Therefore, planning in Cycle-1 needs to be improved so that the next cycle can reach the success criteria.

The researchers found that the reading mastery class X PH 2 students was low. Students' can pass the exam if they get 70 score. The percentage of tests in cycle 1 is $26.47 \%$. From the explanation above, the researchers analyzed several problems in Cycle 1, that students still had difficulty focusing on learning English. In the second cycle, $91.18 \%$, it showed that the teaching and learning process was successful after the Integrated Cooperative and Reading Composition model was used in the class.

Table 1. The table of student's progress in reading comprehension test on cycle 1 and cycle 2

\begin{tabular}{cccc}
\hline CYCLE (1 \& 2) & THE AVERAGE & $\begin{array}{c}\text { NUMBER OF } \\
\text { STUDENTS WHO } \\
\text { PASSED KKM }\end{array}$ & PERCENTAGE \% \\
\hline Pretest Cycle 1 & 50 & 3 & $8.8 \%$ \\
\hline Post Test Cycle 1 & 65 & 9 & $29.41 \%$ \\
\hline Post Test Cycle 2 & 85 & 31 & $91.18 \%$
\end{tabular}

From the table 1 above, the researchers concluded that improving student's reading comprehension using Cooperative Integrated and Reading Composition in SMKN 3 Cimahi is success.

The collecting data which was taken from students' observation, and test could be said that Cooperative Integrated and Reading Composition method could improve students' reading comprehension. The students' could active in improve their comprehension and their ideas when they were collaborated with their friends on the group. It was supported by Choirunisa (2014) that "Cooperative Integrated and Reading Composition have found positive effects on students' reading skills and comprehension, including improved scores on standardized reading and language tests". Thus, the reading comprehension was the results obtained by students after learning a narrative text by Cooperative Integrated and Reading Composition method in the form of qualitative data. 


\section{Observation CAR \\ Cycle 1}

\section{Planning}

In this step, the researchers made a lesson plan about the material that would be applied in the class. The material is about the "Malin Kundang" story. The researchers would teach reading comprehension using CIRC.

2. Acting \& Observing

Cahyaningrum (2010) states that "positive attitudes let learner have positive orientation toward learning English". Students' attitude play crucial role at learning process In this step, the researcher applied what has been planned before. There were the schedule activity that has been done :

Treatment 1 is to give students assignment to analyze a narrative text of Malin Kundang. The students must analyze the main idea, part of speech, and grammar that used in this narrative text.

Treatment 2 is to applying Cooperative integrated and reading composition method through narrative text of Malin Kundang. At this step students divided into some groups in each group contain five persons. The teacher asked every group to get the assignment done in various way, the teacher gives score based on how well a group getting the assignment done. Post Test is given to the students after getting two treatments. The students read a narrative text to get the point of a story and to retell the story by students comprehension ability after getting two treatments.

\section{a. The students attitude}

During activities the students' looked confused because they cannot understood the main idea of the text by reading the narrative text. Because students are just learning for the first time using the circ method, most of them rely more on their group friends.

\section{b. Teacher's Creativity}

By looking the students confused, the teacher asked them to use the dictionary or google translate to help students understanding the main idea of narrative text Malin Kundang.

\section{c. Classroom atmosphere}

The classroom atmosphere is quite uncontrollable, the students look worried and unconfident they make the classroom quite unfriendly.

The researchers observing the student in learning reading comprehension through narrative text of Malin Kundang. At the process of learning activity, students look difficult and they are confused to determine the generic structure in the narrative text given. most of them rely more on their group friends to complete the given worksheet.

\section{Reflecting}

The researchers value of the result post-test in the first cycle in the case want to acknowledge post-test/whether it is improved or not, and it turns out that the results obtained were very unsatisfactory because the students reading comprehension is not work by implementing cycle 1 , they read the narrative text of malin kundang without getting the main idea of the text, there are lots of unfamiliar vocabulary that students havent mastered yet. The students' read the text without getting the main idea of the text. It made the researchers continue on cycle 2 to get better result from this method.

Based on what was found by researcher in cycle 1, the researcher decided to made several revisions to be implemented in Cycle-2 : a) The researchers provided text for each group. Thus, each group gets a different text, b) The researchers distributes the text directly to students', c) 
The researchers recommends that each group open a dictionary, so that they can examine each meaning of words that are difficult or foreign to them.

\section{Cycle 2}

1. Planning

In this step, the researchers made a lesson plan about revised the teaching method that would be applied in the class. The material is about the narrative text. The researchers instructed the students' to reading narrative text about the "Tangkuban Perahu, Jack and the Beanstalk, Timun Emas, The Rabbit and Crocodiles, Cinderella" story.

2. Acting \& Observing

In this step, the researchers applied what has been planned before. There were the schedule activity that has been done :

Table 3. Schedule activities of Cycle 2

\begin{tabular}{lcc}
\hline 1. & $\begin{array}{c}\text { Treatment I } \\
\text { (cycle II) }\end{array}$ & $\begin{array}{c}\text { Give students the assignment to analyze a narrative text } \\
\text { but with billingual language. }\end{array}$ \\
\hline 2. & $\begin{array}{c}\text { Treatment II } \\
\text { (cycle II) }\end{array}$ & $\begin{array}{c}\text { Applied the Cooperative Integrated and Reading } \\
\text { Composition method through narrative text using bilingual } \\
\text { language, each group presents the generic structure of the } \\
\text { narrative text they read. }\end{array}$ \\
\hline 3. & Post test & Give student post test reading comprehension \\
\hline
\end{tabular}

\section{a. The students attitude}

During the activities of students following the teacher's instructions conducively, because students have understood the CIRC method for reading comprehension, students directly discuss with the group to determine the generic structure in the narrative text.

\section{b. Teacher's Creativity}

By making students understand in one explanation, how to find the main idea or generic structure in a narrative text using the CIRC method, therefore the teacher has succeeded in making creativity in the classroom.

\section{c. Classroom atmosphere}

The classroom atmosphere is conducive, the students' looked enjoy their learning process of this method.

In this step the researcher collect data about the reading comprehension obtained by students after conducting Cooperative Integrated and Reading Composition, and analyze the influence of student attitudes in the class.

\section{Reflection}

If the result was reach the KKM, it was not necessary to continue to the next cycle. Fortunately on this second cycle the researchers has got the expected result.

\section{Discussion}

From the statement above, the researchers analyzed that almost the problems in the Cycle -1 could be corrected in the Cycle- 2. Most of the students' scores in the Post-Test 2 could reach the criteria. The students involved themselves in learning English, especially in reading comprehension. The students received the materials in which the teacher used on that days. On the basis of the good results in the Post-Test 2, the researchers did not need to continue the research. From the discussion above, the researcher concluded that using Cooperative 
Integrated and Reading Composition to improve students' reading comprehension in SMKN 3 cimahi was successed.

\section{CONCLUSION}

Based on the result, the researchers conclude that the implementation of Cooperative Integrated and Reading Composition method could improve student's reading comprehension on the tenth grade Vocational High School. It could be proved from the several facts. First, the improvement could be seen from the percentage of students who passed Minimum Mastery Criterion Kriteria Ketuntasan Minimal (KKM). In the first cycle the percentage of students score got $26.47 \%$, and in the second cycle the percentage of students score $91.18 \%$. Second, from the result of field notes the researchers found that the atmosphere of class was different when the students use bilingual language, the students could be more active and improve their ideas. The Cooperative Integrated and Reading Composition method made the students interest to be more active in the class. Moreover, Cooperative Integrated and Reading Composition method would be alternative strategy in improve students reading comprehension.

It was supported by Choirunisa (2014) that "Reading Composition and Integrated Cooperative have found positive effects on students' reading and understanding skills, including increased scores on reading tests and standard language". Thus, reading comprehension is the result obtained by students after learning narrative texts with Integrated Cooperative and Reading methods in the form of qualitative data.

\section{ACKNOWLEDGMENTS}

Praise be to Allah, Cherisher and Sustainer of the world. Who has given the researcher a chance to learn, strength and guidance for the researcher, therefore this journal can be finished. Peace and blessing be upon to prophet Muhammad SAW, his families, his relatives and all followers. This journal is written to fulfill the requirement of the final exam on Sarjana Degree at the English Departement IKIP Siliwangi Bandung. The researcher would like to express great appreciation and thanks to all lectures in English Education Study Program, especially to Miss Rissa San Rizqiya, M.Pd to guide, advise, and motivate the researcher until finish the project. The reserachers also like to show the gratitude to parents, and friends who support the researcher. The researchers realizes this journal far from perfect, but the researcher hope this research can be useful and be reference for the reader or the other researcher in the future.

\section{REFERENCES}

Apsari, Y., \& Yana, Y. (2015). Teachers'techniques And Problems In Teaching Reading. Jurnal Ilmiah P2m Stkip Siliwangi, 2(2), 217-233.

Cahyaningrum, D., Thesis, A., Training, T., \& Faculty, E. (2010). The Effectiveness Of Using Youtube Video In Teaching English Grammar Viewed From Students' Attitude. Website: Http://Ejournal.Radenintan.Ac.Id/Index.Php/Engedu/Article/View/533

Choiri, A. S. (2017). The Use Of Cooperative Integrated Reading And Composition (Circ) Method To Improve Reading Comprehension Ability Of Visually Impaired Students' In The $3 \mathrm{Rd}$ Grade Of Sd Slb A Ykab Surakarta , Indonesia. European Journal Of Special Education Research, 2(1), 59-70. Https://Doi.Org/10.5281/Zenodo.224515

Choirunisa. (2014). Improving The Reading Comprehension Ability Of Grade Viii Students' Of Smp Islam Terpadu Abu Bakar Yogyakarta Through The Use Of Cooperative Integrated Reading And Composition In The Academic Y Website: 
Http://Eprints.Uny.Ac.Id/Id/Eprint/18478

Fitria, T. N. (2015). Improving Students' Reading Comprehension Through Cooperative Integrated Reading Composition (Circ). 1-22.

Friska, Y. (2018). Improving Students' Reading Comprehension Of Narrative Text Through Project Based Learning. Elt-Echo, 3(1), 47-58. Https://Doi.Org/Http://Dx.Doi.Org/10.24235/Eltecho.V3i1.2570.G1566

Indriyanti, R., \& Prasetyo, Z. K. (2018). Improving The Experiment Report Writing Skills Of Fifth Graders Through The Discovery Learning Method. Jurnal Prima Edukasia, 6(1), 102. Https://Doi.Org/10.21831/Jpe.V6i1.17284

Mubarok, H., \& Sofiana, N. (2017). Cooperative Integrated Reading And Composition (Circ) And Reading Motivation: Examining The Effect On Students' Reading Ability. Lingua Cultura, 11(2), 121. Https://Doi.Org/10.21512/Lc.V11i2.1824

Parmawati, A. (2018). The Study Correlation Between Reading Habit And Pronunciation Ability At The Second Grade Students Of Ikip Siliwangi. Eltin Journal, Journal of English Language Teaching In Indonesia, 6(1), 46-52. 